\title{
CONGLOMERATE MERGERS UNDER SECTION 7 OF THE CLAYTON ACT
}

Sectron 7 of the Clayton Act proscribes asset or stock acquisitions that substantially lessen competition or tend to create a monopoly in any line of commerce. ${ }^{1}$ The standards governing the application of this provision are fairly clear in cases where competing concerns are merged ${ }^{2}$ and are rapidly developing in cases where the merger unites concerns that are actual or potential customers or suppliers of each other. ${ }^{3}$ Only recently, however, has section 7 been applied to the so-called conglomerate class of acquisitions. A conglomerate merger can best be defined negatively as one in which the merged firms are neither competitors nor potential or actual customers or suppliers of each other. Recent decisions in The Procter \& Gamble C0.5 case and in Reynolds Metals Co.v. FTC ${ }^{B}$ defining the criteria governing the legality or illegality of conglomerate mergers are significant not only as matters of first impression, but also as indications that some mergers will be held illegal without the traditional investigation into market structure and into the effects of the merger on "competition," investigations that are usually associated with section 7 cases. ${ }^{7}$

1. Section 7 of the Clayton Act, 64 Stat. 1125 (1950), 15 U.S.C. $\$ 18$ (1958), reads in part:

No corporation engaged in commerce shall acquire, directly or indirectly, the whole or any part of the stock or other share capital and no corporation subject to the jurisdiction of the Federal Trade Commission shall acquire the whole or any part of the assets of another corporation engaged also in commerce, where in any line of commerce in any section of the country, the effect of such acquisition may be substantially to lessem competition, or to tend to create a monopoly.

2. These "horizontal" mergers which bring establishments producing similar or uniform products under one management are the most prevalent integrations among manufacturers. Temporary National Economic Committee, Monograph No. 27, "The Structure of Industry" 163 (1941). Between 1951, when the amended Clayton Act took effect, and Jan. 1, 1962, the FTC and the antitrust division of the Justice Department brought 96 cases involving mergers. Sixty-one per cent of these involved cases with horizontal aspects only, and twenty-five per cent had both horizontal and vertical aspects. Bock, Mfergers and Markets, National Industrial Conference Studies in Busmess Econosics No. 77, at $23,24 \& 31$ (1962).

3. Ten of the 96 government actions between 1951 and 1962 involved "vertical" mergers. Id. at 31. For a collection of definitions of vertical mergers by various authorities see Kessler \& Stern, Competition, Contract, and Vertical Integration, 69 YALE L.J. 1 (1959).

4. Congress has described conglomerate mergers as "those in which there is no discernible relationship in the nature of business between the acquiring and acquired firms." H.R. Rep. No. 1191, 81st Cong., 1st Sess. 11 (1949). See Edwards, Conglomerate Bigness as a Soutrce of Power, in Business Concentration and Price Policy 331 n.1 (1955).

5. 3 TrAde Reg. Rep. $\| 15773$ (FTC Order 1962).

6. 309 F.2d 223 (D.C. Cir. 1962).

7. As of April 1961 Professor Handler and Mrr. Robinson found no case under amended section 7 where the FTC terminated its inquiry at the point of receiving market share data. In all of the cases the investigation "pursued further economic lines to promote an informed judgment as to the probable effect of the acquisition on competition:" Handler \& Robinson, A Decade of Administration of the Celler-Kefauter Antimerger Act, 61 CoLvas. L. REv. 629,675 (1961). 
In 1957 Procter \& Gamble-the largest manufacturer of soaps and detergents in the United States, one of the largest advertisers, and an aggressive campaigner in "competitive sales promotion programs"-purchased Clorox," the largest producer of liquid bleach. Although the FTC hearing examiner stated that it was "not necessary that the conglomerate enjoy a predominate position in any industry" 9 in order to violate section 7 , sheer size figured large in his evaluation of the merger's impact on competition. Of related and equal significance, the examiner found, were such factors as the financing, economic strength, advertising, and promotional experience of Procter \& Gamble as compared with that of Clorox's competitors. ${ }^{10}$ Such power was particularly potent in this instance, the trial examiner observed, because of the nature of the product and the marketing methods of the two merging firms. While bleach and soap were not found to be competing items, the products were considered "complementary"; 11 bleach is an adjunct of laundry soap. Clorox was distributed, like soap and many other Procter \& Gamble products, primarily through grocery and chain stores. Since retailers in allocating shelf space favor items which are "pre-sold" through extensive advertising, the examiner reasoned that the coercive strength of Procter \& Gamble's advertising, financial resources, and distribution facilities could readily be summoned to Clorox's aid in the competition for shelf space, and that this gave Clorox a competitive advantage over other bleach products. ${ }^{12}$ In support of this assumption, the examiner noted post-acquisition evidence showing that Clorox's per unit advertising costs were lower while its share of the market rose two and one-half per cent during the year following acquisition. ${ }^{13}$ Finding that competitors in the bleach market had been injured and would continue to be injured, the hearing examiner directed dissolution of the merger. ${ }^{14}$

This analysis and conclusion of the trial examiner portends that the criterion for the invalidity of conglomerate mergers under section 7 will be the economic power of the acquired or acquiring company. Or, as stated by the examiner, the touchstone of illegality is the ability of the merged company to "concentrate

8. Clorox had just under fifty per cent of the market, the next largest producer had fifteen per cent, and the next three in size had but three to six per cent of the markct. The Procter \& Gamble Co., 3 Trade Reg. Rep. $\{15773$, at 20584 (FTC Order 1962).

9. Id. at 20583.

10. Ibid.

11. Ibid. The opinion does not indicate how essential this "complementary" factor was to the FTC's determination of illegality. For a theory on how a monopoly of one complementary product can be extended into the market of another complementary product by means of a tie-in, see Bowman, Tying Arrangements and the Leverage Problem, 67 YALE L.J. 19, $25-27$ (1957). See also Hoyek, The Geometrical Representation of Complemen= tarity, 10 Rev. Econ. Studies 122 (1942-43). 1962).

12. See The Procter \& Gamble Co., 3 Trade Reg. Rep. \ा 15773, at 20584 (FTC Order

13. Ibid.

14. This was the second time that a Commission hearing examiner had found the acquisition of Clorox by Procter \& Gamble to be illegal. After the initial order to cease and desist, the Federal Trade Commission remanded the case for the taking of additional evidence, particularly post-acquisition evidence. The Procter \& Gamble Co., 3 TRadE REG. REP. đI 15245 (FTC Order 1961). 
its competitive efforts at one point by shifting its financial resources and competitive strength from one industry or market to another."16

A still more recent decision, Reynolds Metals Co. v. FTC,10 decided by the United States Court of Appeals for the District of Columbia, involved the first judicial application of this test of merger illegality under section 7. Reynolds Metals, with 40 per cent of the aluminum foil market, was at the time of the merger the nation's largest foil producer. Besides supermarkets and variety stores, aluminum foil is also sold to approximately two hundred aluminum converters who consume "jumbo" rolls of foil by coloring, printing, laminating, or molding it into a myriad of packaging, insulating, and decorative devices; these converters or processors in turn sell the foil to wholesalers. One of these converters of foil, Arrow Brands, Inc., purchasing .0017 per cent ${ }^{17}$ of this country's total production of aluminum foil and selling the converted foil to florists to cover flower pots, was acquired by Reynolds in 1956. Like seven other converters of foil, Arrow was distinguishable from the two hundred aluminum converters by the fact that it called its product "florist foil" and sold this product exclusively to florist supply wholesalers. Among the eight converters selling to florist wholesalers, Arrow was the oldest and largest supplier with 33 per cent of sales, aggregating about $\$ 500,000$.

Although florist foil and other aluminum decorative foil produced by many of the two hundred aluminum converters are identical in use and quality, the court in Reynolds found that the relevant "line of commerce" for determining the market effects of the merger was florist foil, and it concluded that the merger substantially lessened competition within the meaning of section 7 . Though the business of Reynolds and Arrow indicated that the merger was a vertical one involving a supplier and consumer, the court specifically declined to base its finding of illegality on foreclosure concepts of vertical integration. Indeed, the court found that the evidence would not support a finding that Reynolds had illegally foreclosed a substantial market to its competitors $;{ }^{18}$ moreover, the possibility of Arrow's competitors being foreclosed from a source of supply was not mentioned. Instead, the court dealt with the merger as an undifferentiated or conglomerate one, like Procter \& Gamble. And, like the hearing examiner's analysis in the Procter \& Gamble case, the court found that the merger was illegal because Arrow now had access to the huge financial resources and business acumen of Reynolds. This gave Arrow a competitive advantage under the Procter \& Gamble test; for Reynolds could, the court believed, transfer this power into the "florist foil" market and thus drive out Arrow's competitors. ${ }^{19}$ The court heeded this conclusion, notwithstanding that

15. The Procter \& Gamble Co., 3 Trade Reg. Rep. If 15773, at 20583 (FTC Order 1962).

16. 309 F.2d 223 (D.C. Cir. 1962).

17. In 1956 Arrow purchased 500,000 pounds of foil out of the national production of some 292 million pounds. Id. at 225 .

18. Id. at 229 .

19. Post-acquisition factors appear to be of particular importance as evidence of anticompetitive effects in conglomerate merger cases. In Reynolds the court cited an increase in Arrow's sales after acquisition as compared with a decrease in sales by 5 out of 7 of 
florist foil was in no way complementary ${ }^{20}$ to other products produced by Reynolds, and that the Reynolds trademark would give little if any competitive advantage to converters who sold only to florist supply wholesalers primarily interested in price. ${ }^{21}$ Thus, the approach of the Reynolds court appears to be the application of an even more naked test of economic power than that of the FTC examiner in Procter \& Gamble, and one which could be applied to find merger illegality regardless of the merger's characterization as horizontal, vertical, or conglomerate.

The court of appeals' conclusions in Reynolds appear to be based upon economic assumptions that have been demonstrated to be of questionable validity. Thus, for example, in finding the advantage accruing to Arrow in the availability of the financial resources and business acumen of Reynolds restilting from the merger as crucial, the court appeared to assume that the trans-

Arrow's competitors to emphasize the effects of the competitive advantage in the Reya nolds-Arrow merger. Reynolds Metals Co. v. FTC, 309 F.2d 223, 230 (D.C. Cir. 1962). Likewise, in Procter \& Gamble the Commission examiner emphasized that Clorox had increased its share of the bleach market by $2 \frac{1}{2} \%$ after acquisition. The Procter \& Gamble Co., 3 Trade Reg. Rep. If 15773, at 20584 (FTC Order 1962). The Commission had earlier remanded the case to the hearing examiner for consideration of post-acquisition factors. The Procter \& Gamble Co., 3 Trade REg. REP. $\int 15245$ (FTC Order 1961). Comparo this with two cases which allowed the retention of conglomerate acquisitions. In Union Carbide Corp., 3 TRADE REg. REP. If 15503 (FTC Order 1961), the FTC held that the merger of the dominant supplier of a raw material (polyethylene resin) with the dominant processor and reseller of the same raw material (polyethylene film) violated section 7. However, the Commission allowed the supplier, Union Carbide, to retain that part of the business involving synthetic sausage casings, which was a product unrelated to any product made by Union Carbide. But the Commission also remarked that there was no substantial change in the share of the market controlled by the sausage casing business after the acquisition. Should there be such a change in the future, the FTC indicated that it would entertain at new complaint. Id. at 20375. Similarly, the district court in United States v. Aluminum Co. of America, 31 U.S.L. WeEk 2394 (N.D.N.Y. Feb. 12, 1963), recently allowed the merger of Alcoa with a copper cable company. But the court was careful to point out that three years of experience with the merger showed the lack of its harmful effect. Of coursc, post-acquisition factors have been considered in other than conglomerate types of acquisitions, see United States v. E.I. duPont de Nemours \& Co., 353 U.S. 586 (1957), but the extent of the FTC's use of such data in evaluating the conglomerate acquisitions appears unprecedented. See Conglomerate Acquisitions and Post-Acquisition Factors, 5 Trade REa. REP. โf 50108 (Nov. 27, 1961).

20. Professor Bowman has explained that two products complement each other if "an increase in the price of one will not only result in fewer sales of that product but also in fewer sales of the other." Bowman, Tying Arrangements and the Lcveragc Problcm, 67 YALE L.J. 19, 25 (1957). It is diffcult to imagine what is complementary to florist foil because florist foil has so many substitutes, such as decorative foil, household foil, and to at lesser extent, wrapping paper and paint. The great number of substitutes for florist foil make it difficult to find any product which would decrease in sales because of a rise in the price of florist foil. The article that might be considered the most "complementary" is the flower pot itself, and there is no evidence that Reynolds produces flower pots which would need to be wrapped with aluminum foil. Compare this with the hearing examiner's finding in The Procter \& Gamble Co., 3 Trade Reg. Rep. II 15773, at 20583 (FTC Order 1962), that soap and bleach were complementary.

21. Compare this with the housewives' interest in the Procter \& Gamble trademark and the grocers' interest in displaying "pre-sold" articles. See text at note 12 supra. 
ference of these assets from one competitive position to another 22 involves no cost to the merging firms. ${ }^{23}$ But rational businessmen will allocate their resources in such a way as to maximize the return on their entire investment. Therefore if Reynolds, after purchasing Arrow, should invest additional financial resources or business acumen in Arrow, that investment of additional capital and managerial talent must be owing to the fact that it provides a greater return than a similar investment would provide elsewhere. By allocating its resources in this manner Reynolds must forego the potential return on assets that could be invested elsewhere; thus the cost to it would be at least the foregone return of the alternate investment. ${ }^{24}$ If the other aluminum converters have a rate of return on their assets equal to Arrow's, they should be equally capable of obtaining needed additional resources from the existing resource markets. ${ }^{25}$ Unless it is shown that there are impediments in the resource market facing Arrow's competitors, the increased capital necessary for entry or expansion to compete with Arrow will be forthcoming if there are greater than competitive profits to be made in the industry. ${ }^{20}$ Therefore the availability of these resources to Arrow from Reynolds does not warrant the conclusion that Arrow could earn greater than competitive profits in the florist foil market.

To be sure, a particular industry may face imperfections in the capital market

22. The idea of power being transferred from one market to another was frequently advanced in the older vertical integration cases as the economic rationale for a merger's alleged anticompetitive effects. The mechanism for the transfer was usually alleged to be the "cost-squeeze"- the integrated firm, by charging a lower price to the integrated consumer than to the integrated consumer's competitors could give the integrated consumer the power to charge lower prices because of lower costs, and thus the power to drive competitors at the consumer level out of business. The most complete analysis of these cases appears in Bork, Vertical Integration and the Sherman Act: The Legal History of an Econonic Misconception, 22 U. CBI. L. REV. 157 (1954). See particularly this author's sever "judicial notions" distilled from the Sherman Act vertical integration ases, at least six of which involve the transfer of power, id. at 198-200.

Moreover, it was argued in these older vertical integration cases that if a monopoly was involved at the supplier level the monopoly profits at this level could be used to set up a monopoly at the purchasing level through deep pocket financing of the low prices charged by the integrated purchaser. This can be seen as the underlying economic theory in the first decision dealing with vertical integration, United States v. American Tobscco Co., 164 Fed. 700 (2d Cir. 1908). See Bork, supra at 160-61. For a recent but qualified presentation of this argument see DirLaAr \& KaHN, FaIR CoMrpetrmion 147 (1954).

23. This concept is not unprecedented. In United States v. Great Atl. \& Pac. Tea Co., 173 F.2d 79 (7th Cir. 1949), the court explained that A\&P's bachward integrated wholesaler, which sold to both A\&P and A\&P's competitors, could charge A\&P's competitors a commission and apply this to the price charged to A\&P. Thus if an item wes selling in the market at 100, the integrated wholesaler could sell it to A\&P's competitors at 100 and receive from them an additional $5 \%$ commission. This would make the price to A\&P 95 (100 minus the 5\% commission received from A\&P's competitors) while the competitors paid 105. Id. at 84-85. For an extensive analysis and criticism of the case, see Adelarns, A\&P: A Study in Price-Cost Behautor and Public Policy (1959).

24. See Bork, supra note 22 , at $182-84$.

25. This is inherent in the functioning of the price system in a capitalist cconomy. See Sanuelson, Econonics 40-44 (5th ed. 1961).

26. Bork, sipra note 22, at 195. 
rendering access to capital difficult for some of the smaller firms. ${ }^{27}$ Moreover, if one producer has a large reservoir of assets, he may think it profitable to engage in a price-cutting war where others with fewer resources and no desirc or ability to borrow may not. ${ }^{28}$ Such destructive price-cutting could be found violative of section 2 of the Sherman Act as an attempt to monopolize. ${ }^{20}$ But the potential power to successfully engage in a price-cutting war does not itself demonstrate a tendency toward monopoly. And even if the standards for a finding of illegality under section 7 are less rigorous than those under the Sherman Act, ${ }^{30}$ the fact remains that the Reynolds court did not base its finding of illegality on any evidence of predatory price-cutting, either present or potential, on the part of the Reynolds-Arrow combine. In the absence of elements suggesting a tendency toward monopoly such as high concentration within the industry, a trend toward such concentration, serious barriers to entry, or predatory price-cutting behavior by a dominant firm, an increase in economic power resulting from a merger may represent greater competitive efficiency, inherent in larger scale integrated operations; this will benefit consumers if it leads to lower prices, larger quantities, or better quality. Such power does not necessarily imply anti-competitive effects. ${ }^{31}$ Although the in-

27. See Bain, Barriers to New Competition 166 (1956). Also, there may be efficiencies of distribution and advertising expertise inherent in. larger scale integrated operations creating competitive cost saving problems for the small firm. See $i d$ at 201-02. However, Professor Kessler suggests that conglomerate mergers, apparently because they are a method of financing, "may at times act to introduce new competition into areas of the economy where capital barriers to entry do exist." Kessler \& Stern, sttpra note 3, at 19 n.75. Compare this with the "failing company" concept developed in the legislative history of $\S 7$ and in Brown Shoe Co. v. United States, 370 U.S. 294 (1962), discussed infra at note 51. For a collection of literature on the problems confronting small business in abtaining capital, see Kessler \& Stern; supra note 3, at 19-20 n.77.

28. However, if this price-cutting war involves a lower than competitive return, somcthing approaching a monopoly price must be obtained in order to recoup the past losses on lower than competitive return. Yet when prices are raised to obtain a greatcr than competitive return, other competitors will be attracted, absent barriers to entry, and the price must be adjusted accordingly, making it impossible to maintain the monopoly price. However, it is possible that some of the past losses incurred by the surviving firm or firms in a price war might be earned back if a monopoly price could be stubsequently obtained because of the psychological threat to potential entrants that, upon entry, they would be faced with a new price war. If this resulted in warding off new entrants, there would thus be no competitors selling at the lower than monopolistic "competitive" price, and no alternative to the consumer paying the higher monopolistic price.

29. 26 Stat. 209 (1890), as amended, 15 U.S.C. $\$ 2$ (1958). See gencrally NEALE, TuL Antrmbust Laws of the Undted States of America chs. IV, V (1960); Atr'y GeN. Nat'l Comar. Antitrust Rep. 43-60 (1955).

30. See Brown Shoe Co. v. United States, 370 U.S. 294, 318 (1962).

31. It would seem that there is less validity in a transfer of power test when a conglomerate rather than a vertical merger is involved. The primary fear in the vertical cascs was the use of the power to "squeeze" competitors of the integrated entity. Sce note 22 supra. But when a conglomerate merger is involved, where neither the acquired firm nor its competitor rely on the acquiring firm for a source of supply or a market, there is no possibility of a squeeze.

Perhaps in recognition of this the FTC appears to be developing a new theory of "reciprocal favors." In Consolidated Foods Corp., 3 TrADE Reg. Rep. $\| 16182$ (FTC Order 
crement in economic power resulting from a conglomerate merger may injure competitors, for it to rise to the level of injury to competition the competitive advantages secured by the conglomerate merger coupled with the existing imperfections in the particular industry's resource markets must so enhance preexisting market power ${ }^{32}$ as to create substantial barriers to entry. And an economic analysis of market structure, absent in both Reynolds and Procter \& Gamble, is a prerequisite for a finding of such barriers. Thus the condemnation of economic power in these cases appears to be an attempt to couch in economic terms-“substantial lessening of competition"-policy considerations that are not primarily economic. Whether this is justified depends upon an evaluation of the case law under and the legislative history of section 7.

Judicial support of merger illegality based on goals other than economic efficiency can be found in the recent Brown Shoe Co. v. United States ${ }^{33}$ decision, the only current interpretation by the Supreme Court of the purposes and scope of section 7.34 Brown Shoe, the fourth largest shoe manufacturer, having 4 per cent of production merged with G. R. Kinney Co., Inc., the largest "family-style" retail shoe store chain, accounting for 1.2 per cent of

1962), Consolidated Foods, a large diversified processor and seller of food products, purchased Gentry, a manufacturer of dehydrated onion and garlic salts. Many of the food processors from whom Consolidated purchased had a demand for Gentry's product. Defining reciprocity as the practice of firms, overtly or tacitly, making concessions to one another in order to promote their own business interests, id. at 20975, the Commission analogized the buying power of Consolidated, which might be used to coerce Consolidated's suppliers into using Gentry salts as a condition of Consolidated's purcliase of their processed product, to a tying agreement. This gave Consolidated an unfair advantage or a "crushing weapon" to be used against "small, single-line competitors." Id. at 20978. Correlating injury to competitors with injury to competition, see id. at 20979, the Commission found that $\S 7$ had been violated.

This theory of reciprocity in the context of giving the large firm an advantage over small firms is spelled out in Edwards, Conglomerate Bigness As $A$ Source of Ponver, in Business Concentration and Price Policy 331, 342-45 (1955). The major criticism is that reciprocity shows either efficiency or a tendency toward monopoly. If it is efficiency, then the power should not be condemned per se. If monopoly power is involved, then the entity should be condemned for this reason; not because of reciprocal power. The problems of size and power should not be examined apart from the traditional focus on monopoly and efficiency. See Stocking, Comment, in Bustness Concentratron amb Price Polrey $352,354,357$ (1955).

32. Many observers have suggested that the only appropriate market power to condemn is that which approaches a horizontal monopoly. E.g., Bork, supra note 22, at 196; Spengler, Vertical Integration and Antitrust Policy, 58 J. PoL. EcoN. 347, 352 (1950); Hale, Vertical Integration: Impact of the Antitrust Laws Upon Combisations of Sticcessite Stages of Production and Distribution, 49 Cozuar. L. Rev. 921, 940-41, 946-49, 952 (1949). However, DirLaAr \& KAHN, op. cit. supra note 22, at 147, disapprove of this recommendation on the ground that there is no other way to attack a monopoly if it is a "matural" monopoly or patent, or if there is an inelastic supply.

33. 370 U.S. 294 (1962).

34. Two other cases have reached the Supreme Court in which the Government's complaints were based in part upon amended $\S 7$, but both were decided without involving a detailed analysis of the scope and purpose of the 1950 amendment. Jerrold Electronies Corp. v. United States, 365 U.S. 567 (1961), per curiam ; Maryland \& Va. Milk Producers Ass'n v. United States, 362 U.S. 458 (1960). 
sales and also ranking twelfth in shoe manufacturing with .5 per cent of the nation's production. In condemning the vertical aspects of the merger, the Court stated that in addition to the probable anti-competitive effects of the merger, its probable effects upon an economic way of life typified by local control of industry, small businesses, and numerous independent entities must also be considered..$^{35}$ Similarly, in finding the horizontal aspects of the merger illegal, the Court stated that Congress desired to protect the viable, small, locally-owned business even though "occasional higher costs and prices might result." 36 But the Court also stated that the act was intended to protect "competition, not competitors," and that a merger was not rendered illegal "by the mere fact that small independent stores may be adversely affected." 37 Thus the Court explicitly recognized the inconsistency between protecting competition, considered as the most efficient form of business organization in its tise of the profit motive to allocate resources economically, and protecting competitors, regardless of their efficiency. The Court apparently concluded, upon consideration of such factors as the trend toward concentration in the shoe industry, ${ }^{\text {d8 }}$ the history of Brown acquiring retail outlets and forcing Brown shoes through them, ${ }^{39}$ and the probability that Brown's conduct would continue, ${ }^{40}$ that the inconsistency between these goals was not at issue in this case. Although dissolving the merger would protect competitors, upholding it would not clearly protect competition, since the trend toward concentration suggested an incipient trend toward monopoly. Assuming that this trend figured large in the Court's deliberations, the invalidation of the merger was not designed to protect small businesses, but rather to prevent potential effects that would clearly be detrimental to a competitive economy. 41 Thus Brown Shoe can be read as merely a pragmatic attempt to apply the incipiency test demanded by section $7^{42}$ in a case where the facts justified its application. It need not be read as

35. Brown Shoe Co. v. United States, 370 U.S. 294, 315-16 (1962).

36. Id. at 344 .

37. Ibid.

38. The importance of trends in industries was constantly emphasized throughout the opinion. See, e.g., id. at $301,317,331,332,334,345,346$. But see the opinion of Mr. Justice Harlan, id. at 373 , where he states that he reached his conclusion of illegality without considering the findings of the district court regarding the trend in the shoe business. However, Mr. Justice Harlan did discuss the increase in the number of retail stores operated by Kinney since the merger. Id. at 369 .

Before the Supreme Court decision Professor Bork observed that the courts were substituting the concept of trend for the concept of striking down monopoly in its incipiency. He found two difficulties with this. First, because a trend could exist long before there was any "possibility of a lessening of competition," a trend should not be correlated with decreased competition. Second, a trend suggests that larger units are more efficient; thus, a trend might be desirable unless there remained too few competitors for active rivalry. Bork, Anticompetitive Enforcement Doctrines Under Scction 7 of the Clayton Act, 39 Texas L. Rev. 832, 835-36 (1961).

39. Brown Shoe Co. v. United States, 370 U.S. 294, 302 (1962).

40. See $i d$. at $343-44$.

41. See United States v. Aluminum Co. of America, 31 U.S.L. WeEK 2394 (N.D.N.Y. Feb. 12, 1963). After discussing Brown Shoe the court found no trend in the aluminum industry and upheld the merger. See note 19 supra.

42. See Brown Shoe Co. v. United States, 370 U.S. 294, 317 (1962). 
implying illegality in a case where protecting competitors would require impairing competition.

The court in Reynolds Metals did not read Brown Slooe in the manner suggested. Combining the Procter $\mathcal{E}$ Gamble transfer of power test ${ }^{13}$ with the protection of competitors policy suggested by Brown Shoe to be one underlying purpose of Congress in amending section 7 in 1950, th the appellate court based its finding of merger illegality on the mere presence of Reynolds, the implied availability of Reynolds' capital structure and resources, and the threat this power might pose to competitors. The transfer of power test was not used as an economic analysis of the market structure, but rather solely as an analysis of the impact of the merger on individual competitors. This illegal "immediate advantage" over other converters was explained :

The power of the "deep pocket" or "rich parent" for one of the florist foil suppliers in a competitive group where previously no company was very large and all were relatively small opened the possibility and power to sell at prices approximating cost or below and thus to undercut and ravage the less affluent competition. 45

But as indicated above, unless there are barriers to entry, a large conglomeration of assets may mean only greater efficiencies and lower costs for the integrated entity. ${ }^{46}$ From the existence of these efficiencies, which may be translated into lower costs and lower prices, one can easily predict injury to individual, less efficient competitors. In the absence of finding special factors, however, such as a trend toward concentration, foreclosure effects, or evidence of predatory behavior by a dominant firm, it is virtually impossible to find an injury to competition from the mere enlargement of a pool of assets. Consequently, it seems fair to say that the Reymolds court was not at all concerned with competition in the sense of an optimum allocation of resources, with its correlaries of lower prices, higher quality, and increased output. WVhat was important to the court, it seems, was that other "competitors" should not be injured by competition from one who, because of access to greater resources, might be more efficient and thereby achieve lower prices.:

43. See text at note 15 supra. Reynolds, however, clearly did not have the monopoly power on which the vertical evils are predicated. See note 2 supra. While constituting the largest producer of aluminum foil, Reynolds faced keen competition from Alcos and Kaiser, as well as new primary producers of aluminum, which made it impossible to drive converters out of this field by "cost-squeeze" effects and made it unnecessary for entering converters to produce their own aluminum foil. In addition, the behavior of the aluminum industry shows that no "cost-squeeze" was being attempted. In boom years, where primary producers might be expected to supply their integrated needs first, the share of production allocated to independent fabricators was actually higher. 2 WhITNEY, ANTrIRUST PoLIcIES 107 (1958).

44. See text at notes 35-38 sipra. But cf. text at notes $64-70$ infra.

45. Reynolds Metals Co. v. FTC, 309 F.2d 223, 229-30 (D.C. Cir. 1962). Referring to "cost" in this quote, the court seems to have assumed that the "cost" was the same for all competitors. Nevertheless, an integrated entity achieving efficiencies which enable it to sell above its own cost but below competitors' cost, apparently would be condemned also, for it would be the most able to "undercut and ravage."

46. See text at notes 31-32 supra.

47. This should not come as a complete surprise. In 1949 Professor Adelman pointed out: 
Moreover, the Reynolds court stated that the "potential" power emerging from the combination was itself sufficient to bring it within section 7.48 This suggests a per se rule of illegality whenever one of the parties to an acquisition controls a large concentration of economic resources and the merger involves a competitive community populated by commercial pygmies. As the court pointed out, however, the rule is not absolute:

[O]ccasion may well arise where an acquisition superficially similar to the one here condemned by the Commission may be encouraged as necessary to preserve competition, to maintain production levels adequate to meet consumer demand or otherwise to produce "countervailing, competitive, economic, or social advantages." 49

This qualification to the rule is significant in its reliance on the language of the Brown Shoe opinion. Such reliance suggests that the Reynolds court considered the holding in Brown Shoe compelling authority for its formulation of the rule. Brown Shoe, however, does not necessarily compel this formulation. In Brozun Shoe it is arguable that what was crucial to the finding of merger illegality was an observed trend toward concentration and the likelihood of stubstantial foreclosure resulting from the acquisition. ${ }^{60}$ Indeed, the Supreme Court observed that even in such a situation there could be mitigating circumstances preserving the merger's legality. These mitigating circumstances are those summarized by the Reynolds court in the statement quoted above.61 But unlike Brown Shoe, in Reynolds there was no finding of a trend toward concentrintion, and foreclosure effects were explicitly disavowed. ${ }^{62}$ Thus the Rcynolds

[T] ] present trend in antitrust law stands out with fair clarity. Integration may be treated as an offense per se; integration which is efficient and controlled by at rational accounting system is twice vulnerable; a successfully integrated firm which uses its advantage in an aggressively competitive manner is in the worst position of all.

Adelman, Integration and Antitrust Policy, 63 HaRv. L. REv. 27, 76 (1949). And before Reynolds reached the court it was suggested that this was the theory that the Commission was espousing. Kessler \& Stern, supra note 3, at 72. See StafF of House SelEct Comm. on Smali Business, 87th Cong., 2d Sess., Refort on Mergers and Supericoncentration Acoursitions 14-15 (Comm. Print 1962).

48. Reynolds Metals Co. v. FTC, 309 F.2d 223, 230 (D.C. Cir. 1962).

49. Ibid.

50. As the Supreme Court pointed out, the "necessary corollary of these trends is the foreclosure of independent manufacturers from markets otherwise open to them." Brown Shoe Co. v. United States, 370 U.S. 294, 332 (1962). See also id. at 329.

51. The Court in Brozen Shoe drew two examples of mitigating circumstances from the legislative history. First, the "dominant firm" defense, where the merger of two corporations might be allowed if its purpose is to enable the new entity to compete with larger firms dominating the market. Id. at 331, 346. It would seem that it is this mitigating circumstance that the court in Reynolds is referring to with the words "necessary to prescrve" competition" quoted in the text. Second, the Supreme Court in Browen Shoc recognized the "failing company" doctrine, where one of the parties to the merger is facing business failure or has inadequate resources to maintain its competitive position. Ibid. Apparently this is what the Reynolds court contemplated with the words "to maintain production levels adequate to meet consumer demand" quoted in the text.

52. Reynolds Metals Co, v. FTC, 309 F.2d 223, 229 (D.C. Cir, 1962). 
court recognized the mitigating circumstances set out in Broum Shoe as mitigating not present or potential anticompetitive effects but the alleged evil of a concentration of economic resources after a merger in a market of small competitors. In other words, in Reynolds the initial presumption of illegality that can be mitigated attaches to a wholly different economic phenomenon. ${ }^{* 3}$

Establishing a relevant market is a prerequisite for determining whether the effects of a merger or other economic transaction substantially lessen competition or tend to create a monopoly. ${ }^{54}$ The established test for determining the relevant market, until recently at least, has been the interchangeability of use or the "cross-elasticity of demand" between the product and its substitutes."5 In Reynolds, this test appears to suggest a market at least as broad as decorative foil. Florist foil and other types of decorative foil are identical and completely interchangeable. If the price of florist foil increases, the demand for lower priced decorative foil, i.e., decorative foil not presently in the florist foil channel of trade, should increase and the lower priced foil should be substituted for the "florist foil." If, however, the objective is to determine whether competitors are or may be injured rather than to determine whether there is a substantial lessening of competition or a tendency toward monopoly, then the idea of a relevant market takes on a different significance. Some market must still be established in order to determine whether a competitor will be injured by a "deep pocket" entry. .6 This type of market determination, analogous to the

53. Speculating, it might be argued that the words "countervailing competitive, economic, or social advantages" in the quote from Reynolds (text at note 49 supra) allow mitigating circumstances other than the "failing company" and "dominant firm" circumstances (see note 52 supra) to rebut the illegality of a merger injuring competitors. If so, an acquisition by a "deep pocket" might be merely a prima facic illegality, to be balanced against social advantages. Such an interpretation, while perhaps avoiding the per se label, is significant because the burden of proof would be on the defendant to justify the merger, rather than on the FTC to show no competing advantages. Cf. Administrative Procedure Act, $\$ 10(e), 60$ Stat. 243 (1946), 5 U.S.C. \$ 1009(e) (1958); Universal Camera Corp. v. NLRB, 340 U.S. 474 (1951). However, the words, which were in quotation marlis in Reynolds without a citation to their source, almost certainly came from Brottn Shoc. And in Brown Shoe the words were used three pages after the Court's discussion of legislative recognition of the two mitigating circumstances, stpra, in a concluding summary to the vertical integration section of the opinion in the context, "We reach this conclusion [of illegality] because the trend ... may foreclose ... without producing any countervailing competitive, economic, or social advantages." Brown Shoe Co. v. United States, 370 U.S. 294, 334 (1962). In addition, the problem of determining what the language means in Reynolds is amplified because it logically could not encompass efficiency, for it is efficiency which generally gives the competitive advantage in the first place. The lack of circumstances other than the presence of efficiency that the words might be referring to and the use of the words in Brown in a concluding summary suggest that the wording is redundant of the "failing company" and "dominant firm" considerations, which, under Reymolds, would be more like exceptions to a per se rule.

54. See, e.g., United States v. E.I. duPont de Nemours \& Co., 353 U.S. 586, 593 (1957).

55. Reynolds Metal Co. v. FTC, 309 F.2d 223, 226 (D.C. Cir. 1962). After Brontn Shoe it is clear that these tests determine the outer boundaries, the "submarkets" being determined by "practical indicia." Brown Shoe Co. v. United States, 370 U.S. 294, 325 (1962).

56. Thus if A.T. \& T. purchased the sole grocery store in a remote western region and a store in New York City lost sales, is the A.T. \& T. acquisition illegal and will A.T. \& T, 
inquiry into proximate cause in tort law, ship between the merger transaction and the alleged injury to competitors, and to identify the competitors whose injuries are caused by the merger. The court's finding in Reynolds of florist foil, the narrowest of the three possible markets, ${ }^{\text {tg }}$ as the relevant one can only be justified as a determination of whether competitors would be injured by the merger; it cannot be rationalized as a determination of whether there would be a substantial lessening of competition or tendency toward monopoly. To the extent that the Reynolds analysis of relevant market finds support in Brozen Shoe, a thrust of that decision is in the direction of protecting competitors rather than competition.

The Reynolds court found that aluminum florist foil was a sufficiently defined submarket as to constitute a separate product market for antitrust purposes. This finding, which the court purported to rationalize in economic terms, was based upon the existence of distinct pricing ${ }^{60}$ and purchaser identity ${ }^{00}$ within the florist foil market, and the industry and consumer recognition of

be liable in treble damages for the loss? The response to this is obviously no, and the reason is that the A.T. \& T. acquisition did not cause the New York store's loss, since the acquired store and the New York store are not competing in the same market.

57. See 2 Harper \& JaMres, The Law of Torts $\S 20.2$ (1956).

58. Reynolds argued for a market consisting of most of the converted foil for two reasons. First, there was little difference in the product other than an inconsequtential gauge. The decorative foil gauge was .00065 of an inch, the thinnest that could be used without undue tearing while wrapping. Reynolds Wrap, the "household" foil, was .0007 inch gauge, but had previously been .00065 inch. Brief for Petitioner, pp. 27-28, Reynolds Metals Co. v. FTC, 309 F.2d 223 (D.C. Cir. 1962). Second, the 200 other converters had the potential in the form of machinery and skill to produce foil for florist consumption. $I d$. at 31. This cross-elasticity of supply is apparently often overlooked in determining the relevant marlect, even by economists. See Edwards, Use and Abuse of Economics in Antitrust Liligalion, 20 A.B.A. Antrtrust Sectron Report 38, 44 (1962). A narrower market comprising about $5 \%$ of the production of aluminum foil might be decorative foil. All decorative foil is the same gauge and undistinguishable in terms of color, lamination, or embossing. See Reynolds Metals Co. v. FTC, 309 F.2d 223, 227-28 (D.C. Cir. 1962). Yet the court found the market to be "florist foil," the $15 \%$ portion of "decorative foil" sold to florists, even though it recognized that on the basis of use and quality florist foil was not a line of commerce distinct from decorative foil. Id. at 228. See generally Mann \& Lewyn, The Relcvant Market Under Section 7 of the Clayton Act: Two New Cases-Two Differcht Vietts, 47 VA. L. REv. 1014 (1961). The most complete work on the factors involved in a $\$ 7$ market determination is Bock, Mergers and Markets (2d ed. 1962).

59. The court found that the decorative foil sold to florists had a lower price than other decorative foil. Reynolds Metals Co. v. FTC, 309 F.2d 223, 229 (D.C. Cir. 1962).

60. The court found that the sole purchasers of florist foil were the nation's 700 whole sale florist outlets. In addition, the court took notice of the fact that not only had the number of firms serving the florists remained fairly constant, but the same individual firms comprised this number. Id. at 228-29. However, an indication that short-run injury to competitors was the prime consideration is shown by the fact that the FTC had previously refused to grant a petition to reopen proceedings for the presentation of new evidence to show the existence of a new entrant in the florist foil field, division of the R.J. Reynolds Tobacco Co. See Brief for Petitioner, pp. 48-49, Reynolds Metals Co. v. FTC, 309 F.2d 223 (D.C. Cir. 1962). Compare the consideration by the court of post-acquisition cvidence to determine lessening of competition. See note 19 supra. 
the florist foil converting industry as a separate economic entity. ${ }^{01}$ "Distinct pricing" was considered important because the evidence showed that florist foil was sold to florist wholesalers at a price lower than the price paid by other purchasers for decorative foil, an otherwise identical product. Although a distinct price may in some circumstances be significant in establishing the relevant market for determining the impact of a merger on competition, the significance of a different price will depend upon the reason why prices for identical products differ. However, no such examination into the possible reasons for the lower prices charged for the florist foil was undertaken in Reynolds. The apparent reasons, such as lower costs of volume marketing, ${ }^{02}$ or, as indicated in the record, the necessity to lower prices to florists in order to meet the lower prices of foreign competition entering the decorative market through florist supply wholesalers, ${ }^{63}$ suggests that the florist foil submarket was only a shortrun phenomenon. If these were the reasons for lower price of florist foil, it seems fairly clear then, under the traditional tests at least, that the relevant market for determining anticompetitive effects was decorative, not florist foil. Only if market determination is to establish tort causation in a system of protecting competitors are the reasons for the price difference irrelevant. In that case, however, they clearly are irrelevant, for even if the price of nonflorist decorative foil later drops as there is "seepage" of decorative foil sold to florists into other markets for decorative foil, florist foil competitors of Arrow, especially if inefficient, would still suffer injury from the merger during this adjustment period. If prices later rise in the florist foil market, even though an increase in the number of competitors testifies to an absence of entry barriers, a florist foil competitor might still have been injured by the merger while the lower prices prevailed. Similarly, reliance on the existence of distinct florist foil customers-the 700 wholesale florists served by the eight converters-in establishing a relevant sub-market in florist foil, is understandable only if the primary concern is the source and extent of injury to competitors. For, to

61. These are among the "practical indicia" set out in Broum Shoe to be used as a standard for market determination. Brown Shoe Co. v. United States, 370 U.S. 294, 325 (1962). However, other "indicia" mentioned by Brown Shoe applied to the Reynolds facts indicate a market broader than florist foil. The products' "peculiar characteristies and uses" were recognized by the Reynolds court as a factor suggesting decorative foil to be the relevant market. See Reynolds Metals Co. v. FTC, 309 F.2d 223, 228 (D.C. Cir. 1962). Likewise, the "unique production facilities" factor would indicate a market much broader than florist foil for many of the converters not producing florist foil but who had the necessary equipment for such production. See Brief for Petitioner, p. 31, Reynolds Metals Co. v. FTC, 309 F.2d 223 (D.C. Cir. 1962).

62. The Government relied on the fact that florist foil was sold to florist jobbers while other decorative foil was sold to "users" in arguing that florist foil was a distinct market. Brief for Respondent, p. 25, Reynolds Metals Co. v. FTC, 309 F.2d 223 (D.C. Cir. 1962). Without knowing that the court would not accept this argument, petitioner ran some risk in presenting the fact that lower costs were involved when sales were made to wholesalers rather than "users" as an explanation of the price difference. This may explain the absence of such a presentation.

63. See Brief for Petitioner, p. 41, Reynolds Metals Co. v. FTC, 309 F.2d 223 (D.C. Cir. 1962). 
suffer injury, the converter-competitor must lose customers, and it is therefore appropriate to determine whether and to whom these customers shifted in order to ascertain the cause and extent of injury.

Representing the clearest articulation of the policy of protecting competitors even at the expense of efficiencies translatable into consumer benefits, the $R e y$ nolds interpretation of section 7 , with its far-reaching implications for conglomerate and other types of acquisitions, not only does not ineltuctably follow from Brown Shoe, but, more importantly, does not appear to find support in the legislative history of section 7 . Indeed, this legislative history appears to fall short of warranting even the reading of the legislative history found in Brozon Shoe. The Court in Brown Shoe, although admitting that the primary aim of Congress was the protection of competition, ${ }^{84}$ asserted that Congress in passing the 1950 amendment to section 7 was aware of the fact that efficiency might be impaired by the need for protection of competitors. ${ }^{05}$ But what was principally at issue during the hearings on this amendment was whether the antitrust laws at that time were sufficient to stop what was considered to be a trend toward concentration in American industry. ${ }^{66}$ Congress was primarily concerned with

64. "Taken as a whole, the legislative history illuminates congressional concern with the protection of competition, not competitors. ..." Brown Shoe Co. v. United States, 370 U.S. 294, 320 (1962).

65. Id. at 344. This appears to be somewhat inconsistent with the statement of the court quoted supra note 64: if competition is the primary concern, it would seem that it should be allowed to function and eliminate inefficient competitors.

66. In the late 1940's the FTC attempted to show that corporate acquisitions were occurring at a rapid pace and that corporate concentration was thereby being increased to an alarming degree. See FTC, The Merger Movement: A Summary Report 25, 28 (1948); FTC, The Present Trend of Corporate Mergers and Acguisitions (1947), included in Hearings Before a Subcommittee of the House Committec on the Judiciary, 80th Cong., 1st Sess., § 3, at 300 (1947). This touched off a debate regarding the FTC's figures, and Senator Donnell in his minority views on H.R. 2734 maintained that corporate acquisitions had in recent years played only a small part in increasing concentration, relying on Lintner \& Butters, Effects of Mergers on Industrial Concentration, 1940-47, 32 Rev. ECON. AND STat. (1950), reprinted in Hearings on H.R. 2734 Before a Subcommittec of the Senate Committee on the Judiciary, 81st Cong., 1st \& 2d Sess. 371 (1949-50), in which the authors concluded that in contrast to earlier merger movements the merger movement of the 1940's was characterized by acquisitions of small companies by large companics with little effect on concentration. After passage of the 1950 amendment the FTC economists unexpectedly agreed with this conclusion. Bok, Section 7 of the Clayton Act and the Mcrging of Law and Economics, 74 HARv. L. Rev. 226, 232 (1960). Cf. StAFF of House Select Comm. on Smate Business, 87th Cong., 2d Sess., Report on Mergers and Superconcentration Acquistrions (Comm. Print 1962).

Whatever merit the reports on concentration had, they gave added incentive to "close the assets loophole." As passed in 1914 the statute applied only to corporate purchases of stock and did not cover asset acquisitions. 38 Stat. 731 (1914). Furthermore, in interpreting the statute the Supreme Court held that even if the acquisition was of stock, the FTC lost jurisdiction if the shares were exchanged for assets before the filing of a complaint, Swift \& Co. v. FTC, 272 U.S. 554 (1926), or even if the shares were exchanged after the complaint had been filed if it occurred before the issuance of a cease and desist order. Arrow-Hart \& Hegeman Elec. Co. v. FTC, 291 U.S. 587 (1934). Consequently, this "loophole" was felt to be the cause of the undesirable increased concentration and the plugging of it was the over-riding consideration in the legislative history. In the words of one of 
the rising percentages of concentration in industrial markets because it believed that the elimination of competitors would inevitably lead to monopoly, and monopoly was equated with inefficiencies. ${ }^{67}$ Thus when Congress referred to protecting small business entities, and this was seldom, it is probable that it did so because it considered them outposts against the creeping trend toward monopoly. The maintenance of small business entities, therefore, was a step toward ensuring greater efficiencies. ${ }^{68}$ If anything "starkly emerges"60 from the legislative history, it is the lack of understanding by Congress that, absent monopoly concentration, protecting the competitor, or stated differently, idolizing a structure of small businessmen, might be inconsistent with the fundamental aim of competition-to produce abundant goods at low prices. Certainly there is nothing in the history to indicate that Congress, if faced with the choice, would have preferred protection of small business units to the maintenance of workable, yet efficient, competition which passes on efficiencies to consumers. ${ }^{70}$

The general purpose of the antitrust laws is the preservation of a competitive economy to produce abundant goods at low prices. Unlike the Robinson-Patman Act, the amendment to section 7 did not purport to abandon this purpose for a

the sponsors of the amendment, Senator Kefauver, "The bill is not complieated. It proposes simply to plug the loophole in sections 7 and 11 of the Clayton Act." Hearings Before a Subcommittee of the House Committee on the Judiciary, 80th Cong., 1st Sess., § 3, at 4 (1947).

Nevertheless, some resistance remained in Congress to the passage of the amendment in 1947. The chief argument of the opposition at that time was that the Sherman Act was sufficient to prevent asset acquisitions that might injure the public. Id. at 137. Buttressing this argument was the emphasis on the recent Justice Department action seeking an injunction of the purchase of Consolidated Steel Corp. by United States Steel. The fatal blow to this line of argument came the next year when the Supreme Court held that the United States Steel acquisition did not lessen competition under the Sherman Act. United States v. Columbia Steel Co., 334 U.S. 495 (1948). The next year the House Judiciary Committee's report was unanimous in recommending action on closing the "loophole" left open because of inadequate coverage by the Sherman Act, even though 5 of 9 members who had expressed minority views in a previous committee report were still on the committec. Brown Shoe Co. v. United States, 370 U.S. 294, 318-19 n.33 (1962). Fecling a necessity to stop what was felt to be increased concentration as a result of the "loophole," the amendment was passed in 1950. See Bok, supra at 234-35.

67. See Martin, Mergers and the Clayton Act 232 (1959).

68. As Professor Bok has noted, Congress correlated competition with the small entrepreneur "to an extent seldom duplicated in economic literature." Bok, supra note 66, at 236-37.

69. In a dissenting opinion FTC Commissioner Elman has stated "the conclusion which starkly emerges from the legislative history is that the policy expressed by Congress in amending section 7 was political and social, as well as economic." Foremost Dairies, Inc., 3 Trade Reg. Rep. I 15877, at 20592 (FTC Order 1962).

70. See MARTIN, op. cit. supra note 67, at 221-22; Bok, sipra note 66, at 236 ("paucity" of remarks having to do with the effects of concentration on ... efficiency"). See generally for comments on the legislative history, MARTIN, op. cif. supra note 67, at 221-53; Bol, supra note 66, at 233-38; Handler \& Robinson; A Decade of Administration of the CellerKefanver Antimerger Act, 61 Coluar. L. Rev. 629, 652-74 (1961) ; Note, Section 7 of the Clayton Act: A Legislative History, 52 Coluar. L. Rev. 766 (1952). 
policy of protecting competitors. ${ }^{71}$ The Procter \& Gamble and Reynolds cases, however, represent the clearest instances of the use of a per se rule to protect competitors under section 7 . If mergers can be found illegal without an economic analysis of its effects on "competition," all conglomerate acquisitions involving a prosperous purchaser of a small business in a market of small business entities will be suspect. ${ }^{72}$ Because the restrictions thus placed on large pools of assets could seriously affect the efficient flow of investment capital, extensive application of the Reynolds rule may bring with it a frozen industrial structure and a lessening of capital intensive innovations. ${ }^{73}$ Such results clearly were not anticipated by Congress in passing an incipiency statute designed to protect the competitive structure from being undermined. Moreover, the interpretation of section 7 as a promoter of decentralization regardless of costs not only misapplies economics and perhaps law, but also is an inadequate means of protecting competitors, or it may be invoked only when an acquisition is involved.74 Because these interpretations of section 7 portend such far-reaching effects, Brown Shoe, in which the issue was not clearly faced and in which the decision

71. For an introduction to the serious problem raised by protecting competitors in the Robinson-Patman Act context, see ArT'y. Gen. NAT'z CoMm. ANTrTrust Rep. 160-70 (1955) ; Adelman, Integration and Antitrust Policy, 63 HARv. L. Rev. 27, 53-57 (1949); Adelman, Effective Competition and the Antitrust Lazws, 61 HARv. L. REv. 1289, 1334-37 (1948).

72. For instance, it would be as illegal for Procter \& Gamble to make the purchase as it is for Reynolds, since Procter \& Gamble also has a huge financial pool and an abundant supply of managerial talent which might give a "competitive advantage" to the merged unit over the "poorer" and perhaps more inexperienced converters. The same might be true of an acquisition by a corporation owned and controlled by J. Paul Getty, for his enormous personal fortune would apparently be available to give the acquired firm a "deep pocket." Or, if Howard Johnson's purchased a "greasy spoon" in a community serviced only by "greasy spoons," the acquisition probably would have the result of turning the acquired restaurant into a vigorous competitor with financing necessary for remodeling, higher sanitary standards, national advertising, and more flavors of ice cream. This would mean a greater attraction of customers from the other "greasy spoons" and thus would cause injury to "competitors." In addition, a firm is often acquired because of its managerial talent, scientists, or good name. But this could give the purchasing firm an advantage over its competitors and thus would also be suspect under the Reynolds rule.

73. See Bouldnsc, Economic ANalysis 725-26 (3d ed. 1955). This author suggests that if compensation is to be given to a competitor injured by competition, compensation should be paid by society as a whole rather than an individual defendant, and actions should not be taken which would freeze the economic structure. Ibid.

74. See note 1 supra. The inadequacy is apparent in the Reynolds case itself. Arrow merely leased its converting facilities prior to acquisition by Reynolds. Brief for Pctitioner, p. 45, Reynolds Metals Co. v. FTC, 309 F.2d 223 (D.C. Cir. 1962). After acquisition Reynolds financed the purchase of new plant and equipment which then produced almost all of the florist foil. Because these assets were acquired after the merger, the court allowed their retention by Reynolds. Reynolds Metals Co. v. FTC, 309 F.2d 223, 230 (1962). A similar result was reached in Union Carbide Corp., 3 TRADE REG. REP. If 15503, at 20375 (FTC Order 1961), but the Commission felt that ordering the dissolution of the old plant and equipment but allowing retention of the new plant and equipment would add a new competitor in the industry. 
of the Court on protecting competitors or protecting competition is beclouded, should not be read to authorize or compel such an approach to conglomerations of economic power. The complexity of the social and economic policy considerations involved in a determination of whether section 7 is designed primarily to protect competitors or a competitive economy should lead a court to pause before construing it in a manner which works the greatest change in pre-existing law, which invalidates apparently economically useful transactions, and which many believe to be inconsistent with the tenets of a competitive economy. 